\title{
IMPACT OF STORE ENVIRONMENT, PRODUCT DISPLAY AND PROMOTIONAL ACTIVITIES ON IMPULSIVE BUYING BEHAVIOR: MODERATING THE ROLE OF INCOME
}

\author{
Faiza Mehtab, Adnan Ahmed, and Mohammad Faisal Sultan
}

\begin{abstract}
This study is based on applied research and investigates the effect of some vital retail marketing variables such as store environment, product display \& promotional activities on consumers impulsive buying behavior. Within this relationship, the moderating role of income is also tested. Although previously there are several studies associated with the topic, but the subject matter has remained a persistent topic of interest to the marketers and firms alike. To gather the data, survey technique was employed, and the data was collected through secondary authentic sources from consumers visiting selected prominent retail shops from the study area. Thus, the ever-evolving consumers' demand and the nature of the subject it is legitimate to consider the study as one of the pervasive in nature as the study is potent in increase of knowledge in the area of business as well as in academia. Moreover, as with all secondary data studies this study is also supplemented with some limitation as the data collected from developing country like Pakistan is not coherent with the other economies although the value of paper has not been overshadowed and this can be used for applicative reasoning. Similarly, the sample size for the study is 200 respondents and AMOS, SEM, CFA, SPSS \& SMART PLS softwares are used for data analysis. As the major reason for the application of the software is theory building approach associated with the study. Relatedly, the paper is supported by descriptive as well as inferential analysis in order to make findings of the study potent and reliable. The use of the software indicated that there is a relationship between store environment, product display \& promotional activity. Similarly, income plays a strong moderating role between the relationship under study.
\end{abstract}

Keywords: Store Environment, Product Display, Promotional Activity, Impulsive Buying Behavior, Income. 


\section{INTRODUCTION}

Today instinct purchasing / buying converts in a usual behavior of customers. Customers go to market to purchase goods which they need but by chance they buy something they don't need to buy, they feel attractive towards the product and at sudden they buy that product. That kind of products affects most of the peoples and they decided to buy that product on the spot. According to the research of (Anita, 2012) since 1950s many researchers worldwide do research studies on the topic of impulse buying behavior as it has become more interested topic among researchers and it is also beneficial for marketers to understand the most influencing factors that affect impulsive buying behavior of customers, hence the marketers also do deep investigation to find out the factors and improve that factor to create competitive advantage though which they ultimately achieve their company objective.

To study consumer / customer's impulse buying behavior many researchers look over what factors / reasons impact them the most? As it is the basic information for marketers so that they can start a positive relationship among marketers and researchers, so then they can satisfy their consumers and grow their profitability as well. Many of the researchers conduct many researches on impulse buying behavior in developed countries, now this is the time to conduct the study of impulse buying behavior in developing / under develop countries like Pakistan. The basic reason of the study to understand the impulse buying behavior and what factors influences most of the customers.

According to the research of (ABBASI, 2017) impulse buying behavior has now become a question for marketers, as 60 years ago "Clover" gave this concept for the purpose of promotional activities in the market, this attitude was analyzed when the customer show instant and quick purchasing attitude. Moreover according to (Aysen, 2018) Impulse buying has become most important phenomenon and hold interest of many researchers worldwide. Impulse buying is an attitude of customer in which they do unplanned purchasing without thinking about the consequences of that purchase. Hence nowadays impulse buying has become a normal attitude of customer therefore, it is important for marketers and customer to study the factors that mostly affect impulse buying behavior. Although it is mainly observe that impulse buying takes place in many super markets. Hence many supermarkets decision making is done by considering the factors of impulse buying behavior to attract more and more customer towards unplanned shopping and to analyze the factors the present research is on supermarkets of Karachi. According to (Hassan \& Hadiqa, 2018) the concept of store 
environment/atmosphere include (lightening, store display, colors, employees, furniture music) all these aspect create a positive image in the mind of customer which ultimately influence the buying behavior of customer and they do impulsive purchasing. Moreover according to (D., P., \& Castaldo, 2009) study that store environment and exterior and interior design plays an important role in the impulsive decision making of customer. The store environment also changes preferences and perception of customer regarding the product service and product quality ( (Hassan \& Hadiqa, 2018).

Moreover another affecting factor is point of purchase display or product display so therefore according to the research of (Anmol, Rana, \& Fahad, 2017) the product display or window display is a factor that attract the customer to purchase the product like if the product display is attractive it will automatically attract the customer to purchase the product impulsively, hence due to it many superstores or retail shops are working on their stores to provide an attractive store layout or store display to make one time customer a regular customer of their store and it will ultimately increase their revenue and profitability.

Another factor is promotional activity according to the research of (Anmol, Rana, \& Fahad, 2017) many superstores, retail stores etc are using promotional techniques to sale their product and generate high revenue, like sales promotion include discount offer, lower prices, buy one get one free offers all those promotions attract customer towards impulse buying purchase as they play with the mind of customer by providing them low prices or discount offers, likewise advertisement is also a promotional technique which include advertisement through internet, mass media, television and if the advertisement is of any celebrity it emotionally attract the customer and they do impulsive purchasing of the product. Thus the present research is on these three factors and their impact on impulsive buying behavior with the moderating role of income. Moreover if we talk about income availability the study of (Parmar \& Ahmed, 2013) stated that the income level plays as important role in impulsive purchasing like the person with higher income is more engage in impulsive purchasing of good and if the person has lower income they are less sensitive toward the impulsive purchasing of products.

\section{Research Gap}

The Present researcher has studied many researches like the research of (Anmol, Rana, \& Fahad, 2017) they research on the factor affecting impulse buying behavior in Bahawalpur shopping malls. (Aysen, 2018) researched on the determinant factor influencing impulsive 
buying behavior of Turkish customer in supermarkets setting. Therefore, both the research paper covers different factors that affect impulsive buying behavior, the first one do research on Pakistan but on shopping malls and the second one do research on turkey supermarkets. Therefore, the present research cover the three factors that is used by other researchers but the present research is the effect of store environment, product display, promotional activity on impulsive buying behavior with moderating role of income in Karachi supermarkets.

\section{PROBLEM STATEMENT}

According to the research of (Piyush \& Geetha, 2013) they study on the effect of store environment on impulsive buying behavior with positive and negative effect as they stated that store environment factors like lightening, music, store design etc play an important role to attract the customer and create a positive image in the mind of customer to do impulsive purchasing. Moreover according to the research of (Peter \& Vladimir, 2014) they research on the effect of promotional activities in impulsive buying behavior in which they analyze that the different promotional technique has a powerful impact of impulsive purchasing of customer like in store promotional campaign, advertisements and sales discount that push the customer to do impulsive purchasing of products.

The present research is on the effect of store environment, product display and promotional activities on impulsive buying behavior of customer with the moderating role of income availability. The main focus is to analyze the moderating effect of income that how this factor effect the impulsive purchasing of customer. As we know that income availability is the main source for a person to purchase products according to their need. The present research is going to be conducted in one of the developing country Pakistan's city Karachi to better analyze that how these factor effect the impulsive purchasing of customer with the high or low income level of customer.

\section{RESEARCH OBJECTIVES}

To evaluate the effect of Store Environment on Impulsive buying behavior.

To evaluate the effect of Product Display on Impulsive buying behavior.

To evaluate the effect of Promotional Activities on Impulsive buying behavior. 
To evaluate the moderation of Income in the relationship of Store Environment, Product Display and Promotional Activities on Impulsive buying behavior.

\section{SCOPE OF RESEARCH:}

The present research aim is to find out the impact of different factors like store environment, product display and promotional activities on impulsive purchasing of customer with the moderating effect of income availability. Therefore the present research is helpful and applicable for business sector; many marketers could take advantage from the research by analyzing different factors that attract customer to do impulsive purchasing of product. Moreover the present research is on supermarkets it is also helpful and applicable for different mini stores retail outlets, shopping malls etc.

\section{SIGNIFICANCE OF RESEARCH:}

The present research play a significant role in super markets as it includes factors that attract the customer towards superstores and to do impulsive purchasing of products. The superstores could take benefit through these factors to attract more and more customer towards their store which ultimately increase their profitability and revenue. Many different marketers use this research to make improvement in their product display, and can use more attractive promotional activities to attract customer towards their product and do impulsive purchasing. The present research is also beneficial for future researcher who does further research on the different factors affecting impulsive buying behavior.

\section{THEORETICAL FRAMEWORK}

The research of (Anmol, Rana, \& Fahad, 2017)studied different factors affecting impulsive buying behavior like (store atmosphere, point of purchase display, promotional activity, payment facility). Another research of (Alireza \& Hasti, 2011) studied evaluating effective factors on consumer impulsive buying behavior and the factors include (in store display, discount/offers, store apparent characteristics, credit card, personality traits etc). The present research is done on the three external factors (store environment, product display and promotional activities) and its impact on impulsive buying behavior with the moderation of income. The present researchers use these three factors as it is dominant variables in many researches and these factor play a significant role to attract customer towards the impulsive 
purchasing of products. But the present research shows that how these three above variables affect the impulsive buying behavior with the moderation of income.

\section{RESEARCH MODEL}

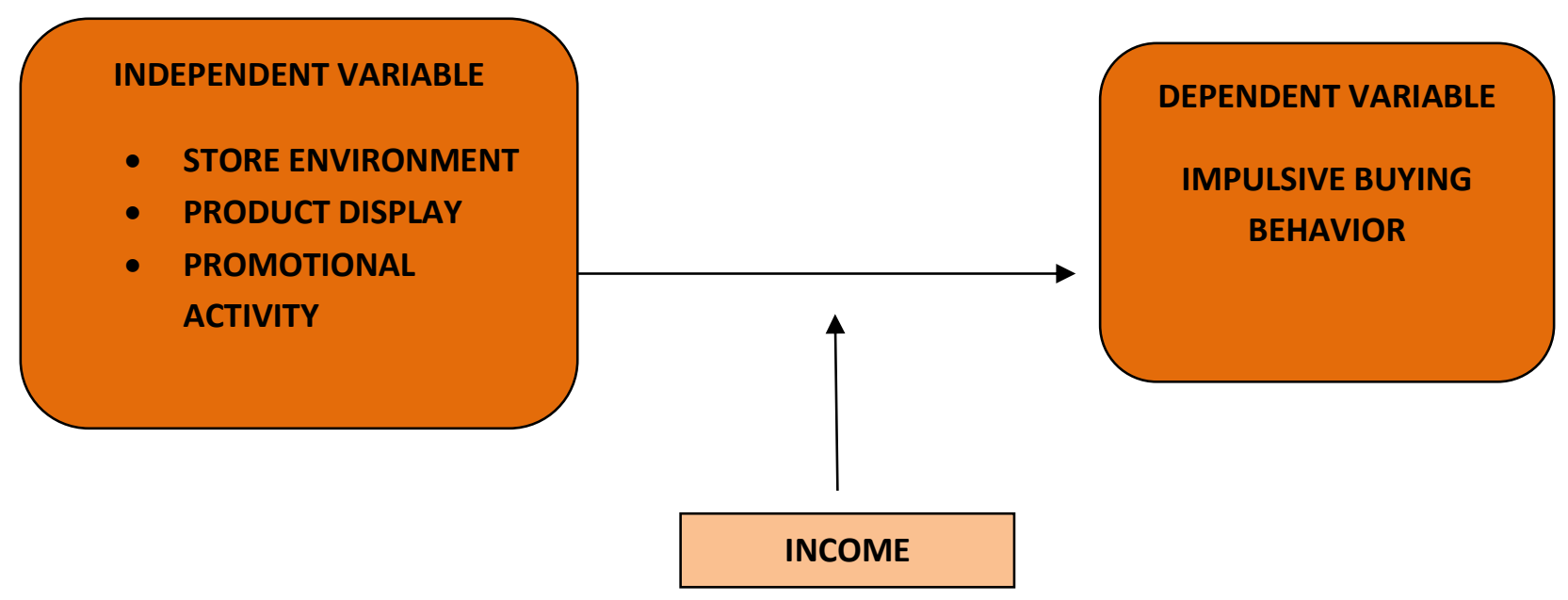

\section{RESEARCH HYPOTHESIS:}

Hal: There is positive relationship of store environment on impulsive buying behavior.

Ha2: There is positive relationship of product display on impulsive buying behavior.

Ha3: There is positive relationship of promotional activities on impulsive buying behavior.

Ha4: Income moderates the relationship of store environment and impulsive buying behavior

Ha5: Income moderates the relationship of product display and impulsive buying behavior

Ha6: Income does moderate the relationship of promotional activities and impulsive buying behavior.

Ha7: There is positive relationship of income with impulsive buying behavior.

Today instinct purchasing / buying converts in a usual behavior of customers. Customers go to market to purchase goods which they need but by chance they buy something they don't need to buy, they feel attractive towards the product and at sudden they buy that product. That kind of products affects most of the peoples and they decided to buy that product on the spot. To study consumer / customer's impulse buying behavior many researchers look over what factors / reasons impact them the most? As it is the basic information for marketers so that they can 
start a positive relationship among marketers and researchers, so then they can satisfy their consumers and grow their profitability as well. Many of the researchers conduct many researches on impulse buying behavior in developed countries, now this is the time to conduct the study of impulse buying behavior in developing / under develop countries like Pakistan. The basic reason of the study to understand the impulse buying behavior and what factors influences most of the customers. The present research chapter 1 discusses the three independent variables (store environment, product display, and promotional activity) and its impact on impulsive buying behavior with moderating role of income. Therefore further in chapter 2 and chapter 3 the researcher will show the literature review and testing on these above variables which will ultimately grab the attention of audience.

\section{LITERATURE REVIEW:}

\section{Store Environment And Impulsive Buying Behavior:}

According to the research of (JONES, REYNOLDS, WEUN, \& BEATTY, 2003) store environment influence the impulsive buying behavior of each and every individual that came for shopping because if the environment of store is so peaceful and pleasant and provide physical ease than its ultimately influence them to shop and purchase products for longer period of time, hence it show that store environment plays an important and positive impact on impulsive buying behavior of customer. Moreover the research of (UMAIR, PENG, MUHAMMAD, MUHAMMAD, \& SHAHID, 2016) the store put different efforts to attract customers like store environment includes such factors, background music, air conditioning, peace, color, theme decoration etc these entire factors influence the emotions of customer which ultimately attract customer and create a positive impact on impulsive purchasing of customer. (HIO, RUOH, \& MOLLY, 2014) Store atmosphere is an effort made by stores to design stores in a way that emotionally impact the mind of customers towards stores and change their attitude and perceived image regarding stores and also states that different store environment characteristics create positive image regarding the product quality which influence them to do impulsive purchasing hence the store environment create a positive relation between store environment and impulsive purchasing

\section{Store Environment And Income:}

According to the research of (HIO, RUOH, \& MOLLY, 2014) income is the major factor while shopping because people positive emotions affect through income availability if people have 
high income then automatically people feel happy and show a positive behavior towards store environment and on the other hand customer with low income show some different emotions towards the store environment which ultimately effect the impulsive purchasing of customer, through this research the evidence shows that income moderates a positive relation in between store environment and impulsive buying behavior. Moreover according to (GALIS \& KABUL, 2016) the money factor is a main facilitator in impulsive purchasing of individual as if the people want to do impulsive buying and they do not have income than the store environment do not play any significant role and the people with proper income will push them towards the impulsive purchasing by enjoying the store environment.

\section{Product Display And Impulsive Buying Behavior:}

According to the research of (JIYEON, 2003) product display or visual display attract customer towards the impulsive purchasing or we can say if the store display is attractive then it will create a positive image in their mind and it will ultimately push them to get inside the stores and if they are successful to attract the customer then the customer will definitely buy a lot of product and do impulsive purchasing of products, thus the evidence prove that product display has a positive impact on impulse buying behavior. Moreover according to (Anmol, Rana, \& Fahad, 2017) point of purchase display attract customer towards impulsive buying which ultimately increase store revenue or profit, it increases store image because if the store display is excellent than it is beneficial for store and if this factor is not good it create negative image in customer minds. (JAMNANI \& DHADDIKAR, 2015) Research stated that store display is an art to design store flours and window in a way that attract more and more customer or we can say create customer traffic in stores, hence it create a unique identity of stores. Therefore evidence shows a positive relation between product display and impulsive buying behavior.

\section{Product Display And Income:}

According to the research of (VOHS, 2007) income is a major factor now a days to deal with shopping, like the customers whose planned shopping resources reduced or they think not to buy because there is something that is attractive to buy it will push them toward the impulsive purchasing, therefore different marketing techniques like visual display is used to attract customer to do unplanned purchasing if they have extra money in hand. It will ultimately show a positive relation between product display and income. Moreover according to the research of (GAURAV, 2011) the researcher stated that store display or product display attract customer 
to spend more on unplanned purchasing product as if the display is attractive than and if they do not have enough money then they will again visit the store with that sufficient money to buy the product which they do not buy last time and if they have money they will do impulsive purchasing, hence the evidence show that there is an impact of product display on income.

\section{Promotional Activities And Impulsive Buying Behavior:}

According to the research of (GALIS \& KABUL, 2016) promotional techniques influence customer towards impulsive purchasing, like in store promotion include (buy one get one free offer, discount offers, advertisement, samples, coupon) all these tools are used by retail stores that easily communicate to customers and engage them towards unplanned or impulsive purchasing, thus it show a direct impact of promotional activities on impulsive buying behavior. Moreover according to (TENDAI \& CRISPEN, 2009) promotional tools like discounts, low prices, buy one get one free offers all those tools create a positive image in the mind of customer and they will spend their money which they save and buy all those product which they do not plan to buy or sometimes they spend some extra money on those thing which is not important but attract them that means they do impulsive purchasing of that product therefore it show a positive direct impact of promotional activities on impulsive buying behavior of customer. (MAHSHID, 2016) research stated that impulse buying behavior in which customer purchase unplanned product which they don't plan before entering the store but there is some promotional factor which grab the attention of customers and develop interest towards the unplanned products and thus the customer do not controlled and do impulsive purchasing of product which show a positive impact of promotional activities on impulsive purchasing.

\section{Promotional Activities And Income:}

According to the research of (VIDHA, 2016) the promotional activities plays an important role in impulsive purchasing like customers with sufficient money gets different promotional offers or money benefit then they also purchase those things that are not planned as well as the planned products, thus we can different promotional tools helps customer to buy more products with their sufficient income and shows a positive relationship between promotional activities and income. Moreover according to the research of (ZAEEMA \& HAIDER, 2018) many retail stores uses promotional techniques like different type of sales promotions which create different choices for customers due to which they do impulsive purchasing and spend on more 
and more on those product which they do not plan to buy thus it will automatically increase their income spending on different product and create a positive impact of promotional activities on impulsive buying behavior of customer.

\section{Income And Impulsive Buying Behavior:}

According to the research of (Anita, 2012) the household income is a major factor that attract customer towards unplanned purchasing as they stated that people with high household income not planned things to buy they do unplanned impulsive purchasing while the people with the people with low income tend not to avoid impulsive purchasing but it depends on several factors that attract them to purchase unplanned product hence it shows that income and impulsive purchasing is related. Moreover according to the research of (MUDASSIR, BUSHRA, FAUZIA, \& MUHAMMAD, 2019) Income is a important factor in the process of impulsive buying like people take money with them when they go for shopping and they can change their planned list or have some unplanned products to buy if they have more money to spend so we can say that more money availability have a significant impact on impulsive buying. According to the research of (Anmol, Rana, \& Fahad, 2017) income is a major factor in impulsive buying like people who earn high income face no problem regarding purchasing and they usually $\mathrm{di}=\mathrm{o}$ impulsive buying and purchase product with higher prices but on the other people with low income faces issues while purchasing the product that is out of their income reach if they came in their budget then they o impulsive purchasing but if it is of higher prices than they do not buy the product hence we can say that there is a relationship between income and impulsive buying behavior.

\section{RESEARCH METHODOLOGY}

According to the research of (PHILLIMORE \& GOODSON, 2004) epistemology is the study and development of knowledge and its aim is to construct knowledge of something and to analyze the nature of knowledge. Therefore the present research is Epistemology because it shows different determinants affecting impulsive buying behavior and it is knowledgeable for many different marketers and increases the knowledge of business and industrial sector.

The realism or post positivism research stance is to challenge a past theory or research and behalf of it new methods of research to be used to obtained more revised and reliable result for research, it could also me done by adding mediator or moderators in the topic to do research with some new variables. Therefore the present research is post positivism or realism research stance which challenges the past theory and adds a moderator income to evaluate the 
relationship between store environment, product display and promotional activities with impulsive buying behavior.

\section{Research Approach:}

According to the research of (SAUNDERS, LEWIS, \& THRONHILL, 2007) the deductive approach is an approach which follow a forward movement (general to specific). Deductive method starts from theory and end with research result which is consist of research question, hypothesis and then data collection after that the testing applied and the research result obtained. Therefore the present research follow deductive approach because it moves from general to specific, it obtained research hypothesis and the data collection is done to obtained the research result.

\section{Research Method:}

According to the research of (CRESWELL, 2002) quantitative method is a method which analyze the data that is quantifiable or numeric form by Applying different statistical tools and mathematical model. Therefore the present research follows a quantitative method because it will use different statistical tools for testing and the data is collected in numerical form.

\section{Research Strategy:}

The present research is quantitative and follow a deductive method so the research strategy could be (survey, experiment or archival).According to the research of (SAUNDERS, LEWIS, $\&$ THRONHILL, 2007) the survey strategy is a result of deductive approach and it collect large amount of data and the use it for statistical analysis and then result obtained for hypothesis whether it is accepted or rejected. Therefore the present research strategy is survey because it obtained questionnaire for the collection of large amount of data and then the testing is applied for research result.

\section{Research Choice:}

According to the research of (SAUNDERS, LEWIS, \& THRONHILL, 2007) mono choice for research is takes place when the research method is either qualitative or quantitative or the research data is collected from one type of method. Therefore the present research choice is mono method because the research follows only one method that is quantitative for research study and they use one research instrument questionnaire for data collection.

\section{Purpose of Research:}


The descriptive research is in which we study different determinants or factor of one variable (UME, 2010) and the co-relational research is a research in which we evaluate the relationship of different variables with some moderator or mediator. Therefore the present research is descriptive and co-relational study because it consists of different factor of impulsive buying behavior with the moderation of income through which the relationship would be analyzed between the variables.

\section{Researcher Interference And Nature Of Experiment:}

If the researcher's interference is more than minimum like they collect data through interview and questionnaire by interacting with different people that is said to be moderate interference of researcher (UME, 2010). Therefore the present researcher shows a moderate interference by collecting the data through questionnaire. According to (UME, 2010) if researcher show a moderate interference for collecting data than the nature of experiment is field experiment in which the researcher will obtain different opinions of sample population through questionnaire, therefore the present research nature of experiment is field experiment.

\section{Sampling Design:}

\section{Population:}

Population is a whole number of people living in a country with a different set of characteristics and sample size is the subset of that population (AMITAV \& SUPRAKASH, 2010). The present research covers the population of Karachi which is one of the city of Pakistan.

\section{Sampling Technique And Method:}

According to the research of (Anmol, Rana, \& Fahad, 2017), (Aysen, 2018), (VIDHA, 2016) the three of the researcher uses non-probability sampling technique by using convenience sampling method. Likewise, the present researcher uses non probability technique because the population is not known and collect data through convenience sampling to reduce time and cost.

\section{Sample Size:}

The sample size for the present research is 200 .

\section{Questionnaire:}

According to the research of (Saunders et al, 2009) questionnaire is a research instrument consist of questions and it is developed to gather data and check the relationship between different variables. Therefore the present researcher uses questionnaire instrument to gather 
relevant data and each variable consist of five questions. The questionnaire is adaptive because the data is collected from different research papers.

\section{Questionnaire Scale:}

The present researcher built questionnaire on likert scale comprising of options that are strongly agree, agree, neutral, strongly disagree, disagree. The questionnaire is built on balanced Likert scale. Hence the demographic part of questionnaire is built on nominal scale application that is dichotomous and category scale.

Furthermore, after collecting data and ready to start the further testing and analysis so for this we have to make sure that our data is valid and ready for further testing so for this purpose we check missing values and unengaged responses and after testing is all the data is valid and ready for further testing. The statistical tools use for testing is SMART-PLS AND SPSS.

\section{RESULT AND ANALYSIS:}

\section{Demographic Variables}

\section{Table 1 Gender}

\begin{tabular}{|c|l|l|l|l|}
\hline & Frequency & Percent & Valid Percent & $\begin{array}{l}\text { Cumulative } \\
\text { Percent }\end{array}$ \\
\hline Valid male & 110 & 55.0 & 55.0 & 55.0 \\
\hline female & 89 & 44.5 & 44.5 & 99.5 \\
\hline Total & 200 & 100.0 & 100.0 & \\
\hline
\end{tabular}

The above table- 1 shows that there are total 200 respondent in which 110 respondents were male and 89 respondent are female. Moreover the above table shows frequencies and percentage of gender.

TABLE 2 Age 


\begin{tabular}{|c|l|l|l|l|}
\hline & Frequency & Percent & Valid Percent & $\begin{array}{l}\text { Pumulative } \\
\text { Percent }\end{array}$ \\
\hline Valid 20 below & 6 & 3.0 & 3.0 & 3.0 \\
\hline 21 to 30 & 142 & 71.0 & 71.0 & 74.0 \\
\hline 31 to 40 & 42 & 21.0 & 21.0 & 95.0 \\
\hline 41 to 50 & 9 & 4.5 & 4.5 & 99.5 \\
\hline 50 above & 1 & .5 & .5 & 100.0 \\
\hline Total & 200 & 100.0 & 100.0 & \\
\hline
\end{tabular}

The above table shows the respondent in which 3\% respondent were below 20 age, $71 \%$ respondent were in between 21 to 30 age, $21 \%$ respondent were between 31 to 40 age, $4.5 \%$ respondent were between 41 to 50 age and $.5 \%$ respondent were 50 above age.

Table 3 Qualification

\begin{tabular}{|l|l|l|l|l|}
\hline & Frequency & Percent & Valid Percent & $\begin{array}{l}\text { Cumulative } \\
\text { Percent }\end{array}$ \\
\hline Valid matriculation & 3 & 1.5 & 1.5 & 1.5 \\
\hline intermediate & 19 & 9.5 & 9.5 & 11.0 \\
\hline bachelors & 110 & 55.0 & 55.0 & 66.0 \\
\hline masters & 54 & 27.0 & 27.0 & 93.0 \\
\hline $\begin{array}{l}\text { diploma } \\
\text { certification }\end{array}$ & 11 & 5.5 & 5.5 & 98.5 \\
\hline others & 3 & 1.5 & 1.5 & 100.0 \\
\hline The & 200 & 100.0 & 100.0 & \\
\hline
\end{tabular}

above table shows the respondent qualification like $1.5 \%$ respondent are matriculate, $9.5 \%$ 
respondent are intermediate and etc all of the respondent frequency and percentage of qualification is mention on the above table.

TABLE 04 House hold Income

\begin{tabular}{|l|l|l|l|l|}
\hline & Frequency & Percent & Valid Percent & $\begin{array}{l}\text { Cumulative } \\
\text { Percent }\end{array}$ \\
\hline Valid 25000 below & 17 & 8.5 & 8.5 & 8.5 \\
26000 to 50000 & 75 & 37.5 & 37.5 & 46.0 \\
51000 to 75000 & 48 & 24.0 & 24.0 & 70.0 \\
76000 to 100000 & 38 & 19.0 & 19.0 & 89.0 \\
others & 22 & 11.0 & 11.0 & 100.0 \\
Total & 200 & 100.0 & 100.0 & \\
\hline
\end{tabular}

The above table 04 shows the frequency of respondent and show percentage in which $8.5 \%$ respondent income is below 25000, 37.5\% respondent income is in between 26000 to 50000 and etc shows the percentage of respondent household income which is given in above table 04 .

Reliability And Validity:

\begin{tabular}{|l|l|l|l|l|}
\hline & $\begin{array}{l}\text { Cronbach's } \\
\text { Alpha }\end{array}$ & rho_A & $\begin{array}{l}\text { Composite } \\
\text { Reliability }\end{array}$ & $\begin{array}{l}\text { Average Variance } \\
\text { Extracted (AVE) }\end{array}$ \\
\hline INCOME & 0.799 & 0.704 & 0.792 & 0.786 \\
\hline $\begin{array}{l}\text { IMPULSIVE BUYING } \\
\text { BEHAVIOR }\end{array}$ & 0.719 & 0.728 & 0.800 & 0.752 \\
\hline Moderating Effect 1 & 0.843 & 1.000 & 0.829 & 0.920 \\
\hline Moderating Effect 2 & 1.000 & 1.000 & 1.000 & 1.000 \\
\hline Moderating Effect 3 & 1.000 & 1.000 & 1.000 & 1.000 \\
\hline $\begin{array}{l}\text { PROMOTIONAL } \\
\text { ACTIVITY }\end{array}$ & 0.810 & 0.815 & 0.790 & 0.732 \\
\hline PRODUCT DISPLAY & 0.733 & 0.753 & 0.820 & 0.718 \\
\hline STORE ENVIRONMENT & 0.818 & 0.888 & 0.867 & 0.672 \\
\hline
\end{tabular}

According to the reference of (TAVAKOL \& DENNICK, 2011) the cronbach's alpha, rho_A and composite reliability values shows reliability and internal consistency, whereas according to the reference the acceptable value of cronbach's alpha, rho_A and composite reliability is 0.70 or greater than 0.70 . As we can see on the above table 05 that all the values of Cronbach's 
alpha, rho_A and composite reliability is 0.70 and $>0.70$ thus the data is reliable. Moreover according to the research of (HAIR \& BLACK, 2014) the average variance extracted shows convergent validity and its acceptable value is 0.5 or $>0.5$ where as we can see on the above table that all the values of AVE is $>0.5$ which shows that the data is reliable and valid for further testing.

\section{Discriminant Validity:}

Table 6 Fornell-Larcker Criterion:

\begin{tabular}{|c|c|c|c|c|c|c|c|c|}
\hline & I & IB & $\begin{array}{l}\text { Moderating } \\
\text { Effect } 1\end{array}$ & $\begin{array}{l}\text { Moderating } \\
\text { Effect } 2\end{array}$ & $\begin{array}{l}\text { Moderating } \\
\text { Effect } 3\end{array}$ & PA & PD & SE \\
\hline I & 0.660 & & & & & & & \\
\hline IB & 0.296 & 0.672 & & & & & & \\
\hline $\begin{array}{l}\text { Moderating } \\
\text { Effect } 1\end{array}$ & $\begin{array}{l}- \\
0.083\end{array}$ & 0.175 & 0.424 & & & & & \\
\hline $\begin{array}{l}\text { Moderating } \\
\text { Effect } 2\end{array}$ & $\begin{array}{l}- \\
0.120\end{array}$ & 0.160 & 0.371 & 1.000 & & & & \\
\hline $\begin{array}{l}\text { Moderating } \\
\text { Effect } 3\end{array}$ & $\begin{array}{l}- \\
0.193\end{array}$ & $\begin{array}{l}- \\
0.012\end{array}$ & 0.461 & 0.412 & 1.000 & & & \\
\hline $\mathrm{PA}$ & 0.351 & 0.428 & 0.162 & 0.175 & 0.056 & 0.658 & & \\
\hline PD & 0.436 & 0.279 & 0.223 & 0.031 & 0.005 & 0.380 & 0.691 & \\
\hline SE & 0.256 & 0.338 & 0.121 & 0.005 & -0.122 & 0.524 & 0.318 & 0.756 \\
\hline
\end{tabular}

Table 7 Cross-Loadings

\begin{tabular}{|l|l|l|l|l|l|l|l|l|}
\hline & INCOME & IB & $\begin{array}{l}\text { Moderating } \\
\text { Effect 1 }\end{array}$ & $\begin{array}{l}\text { Moderating } \\
\text { Effect 2 }\end{array}$ & $\begin{array}{l}\text { Moderating } \\
\text { Effect 3 }\end{array}$ & PA & PD & SE \\
\hline IB1 & 0.186 & 0.597 & 0.025 & -0.021 & -0.110 & 0.229 & 0.198 & 0.167 \\
\hline IB2 & 0.224 & 0.795 & 0.211 & 0.130 & 0.048 & 0.339 & 0.194 & 0.342 \\
\hline IB3 & 0.287 & 0.796 & 0.079 & 0.100 & -0.034 & 0.339 & 0.205 & 0.271 \\
\hline IB4 & 0.088 & 0.637 & 0.102 & 0.141 & 0.016 & 0.277 & 0.218 & 0.182 \\
\hline IB5 & 0.177 & 0.483 & 0.146 & 0.188 & 0.012 & 0.230 & 0.132 & 0.109 \\
\hline PA1 & 0.295 & 0.269 & 0.154 & 0.032 & -0.008 & 0.642 & 0.325 & 0.357 \\
\hline PA2 & 0.309 & 0.213 & 0.071 & -0.001 & -0.026 & 0.633 & 0.245 & 0.369 \\
\hline PA3 & 0.211 & 0.318 & 0.166 & 0.179 & 0.023 & 0.726 & 0.245 & 0.368 \\
\hline
\end{tabular}




\begin{tabular}{|c|c|c|c|c|c|c|c|c|}
\hline PA4 & 0.228 & 0.331 & 0.086 & 0.136 & 0.075 & 0.738 & 0.241 & 0.387 \\
\hline PA5 & 0.132 & 0.250 & 0.041 & 0.199 & 0.105 & 0.525 & 0.202 & 0.238 \\
\hline $\mathrm{PD} * \mathrm{I}$ & -0.120 & 0.160 & 0.371 & 1.000 & 0.412 & 0.175 & 0.031 & 0.005 \\
\hline PD1 & 0.318 & 0.199 & 0.137 & 0.072 & 0.061 & 0.324 & 0.714 & 0.259 \\
\hline PD2 & 0.354 & 0.116 & 0.102 & -0.101 & 0.000 & 0.323 & 0.672 & 0.177 \\
\hline PD3 & 0.341 & 0.171 & 0.083 & -0.054 & -0.056 & 0.286 & 0.665 & 0.290 \\
\hline PD4 & 0.263 & 0.259 & 0.205 & 0.064 & -0.046 & 0.221 & 0.780 & 0.209 \\
\hline PD5 & 0.282 & 0.171 & 0.213 & 0.057 & 0.073 & 0.209 & 0.615 & 0.162 \\
\hline $\mathrm{SE} * \mathrm{I}$ & -0.193 & $\begin{array}{l}- \\
0.012\end{array}$ & 0.461 & 0.412 & 1.000 & 0.056 & 0.005 & -0.122 \\
\hline SE1 & 0.231 & 0.345 & 0.075 & 0.025 & -0.090 & 0.457 & 0.270 & 0.813 \\
\hline SE2 & 0.253 & 0.321 & 0.103 & -0.012 & -0.135 & 0.498 & 0.326 & 0.885 \\
\hline SE3 & 0.172 & 0.203 & 0.091 & -0.009 & -0.163 & 0.343 & 0.196 & 0.797 \\
\hline SE4 & 0.134 & 0.167 & 0.162 & 0.030 & -0.018 & 0.348 & 0.170 & 0.688 \\
\hline SE5 & 0.119 & 0.130 & 0.045 & -0.028 & -0.006 & 0.257 & 0.187 & 0.555 \\
\hline i1 & 0.623 & 0.145 & -0.062 & 0.044 & -0.151 & 0.351 & 0.313 & 0.216 \\
\hline i1 * PA1 & 0.021 & 0.074 & 0.506 & 0.150 & 0.286 & 0.041 & 0.054 & 0.071 \\
\hline $\mathrm{i} 1 * \mathrm{PA} 2$ & -0.013 & $\begin{array}{l}- \\
0.003\end{array}$ & 0.295 & 0.053 & 0.254 & $\begin{array}{l}- \\
0.015\end{array}$ & $\begin{array}{l} \\
0.001\end{array}$ & -0.025 \\
\hline i1 * PA3 & -0.020 & 0.044 & 0.493 & 0.191 & 0.365 & 0.116 & 0.117 & -0.010 \\
\hline i1 * PA4 & -0.010 & $\begin{array}{l}- \\
0.016\end{array}$ & 0.377 & 0.164 & 0.344 & 0.025 & 0.033 & -0.041 \\
\hline i1 * PA5 & 0.012 & 0.066 & 0.433 & 0.133 & 0.206 & 0.114 & 0.138 & 0.106 \\
\hline i2 & 0.680 & 0.171 & 0.008 & 0.045 & -0.085 & 0.183 & 0.378 & 0.042 \\
\hline $\mathrm{i} 2 *$ PA1 & 0.007 & 0.144 & 0.591 & 0.291 & 0.204 & 0.104 & 0.142 & 0.065 \\
\hline $\mathrm{i} 2 * \mathrm{PA} 2$ & -0.019 & 0.033 & 0.368 & 0.188 & 0.163 & 0.024 & 0.097 & 0.017 \\
\hline $\mathrm{i} 2 * \mathrm{PA} 3$ & 0.050 & 0.053 & 0.568 & 0.238 & 0.279 & 0.182 & 0.161 & 0.078 \\
\hline $\mathrm{i} 2 * \mathrm{PA} 4$ & 0.029 & 0.004 & 0.417 & 0.203 & 0.314 & 0.079 & 0.109 & 0.056 \\
\hline $\mathrm{i} 2 *$ PA5 & -0.042 & 0.042 & 0.509 & 0.229 & 0.249 & 0.121 & 0.154 & 0.032 \\
\hline i3 & 0.785 & 0.260 & -0.055 & -0.161 & -0.138 & 0.281 & 0.308 & 0.208 \\
\hline $\mathrm{i} 3 * \mathrm{PA} 1$ & -0.037 & 0.041 & 0.310 & 0.322 & 0.184 & 0.036 & $\begin{array}{l}- \\
0.041\end{array}$ & -0.002 \\
\hline i $3 *$ PA2 & -0.068 & $\begin{array}{l}- \\
0.079\end{array}$ & 0.164 & 0.233 & 0.187 & $\begin{array}{l}- \\
0.060\end{array}$ & $\begin{array}{l}- \\
0.035\end{array}$ & -0.014 \\
\hline $\mathrm{i} 3 * \mathrm{PA} 3$ & -0.030 & 0.065 & 0.539 & 0.182 & 0.346 & 0.034 & 0.130 & -0.040 \\
\hline $\mathrm{i} 3 * \mathrm{PA} 4$ & -0.133 & 0.089 & 0.574 & 0.225 & 0.316 & 0.021 & 0.061 & 0.030 \\
\hline i3 * PA5 & -0.045 & 0.039 & 0.468 & 0.182 & 0.252 & 0.079 & 0.158 & 0.053 \\
\hline $\mathrm{i} 4$ & 0.570 & 0.132 & -0.151 & -0.265 & -0.206 & 0.201 & 0.239 & 0.229 \\
\hline i4 * PA1 & -0.124 & $\begin{array}{l}- \\
0.015\end{array}$ & 0.096 & 0.174 & 0.222 & $\begin{array}{l}- \\
0.013\end{array}$ & $\begin{array}{l}- \\
0.061\end{array}$ & -0.122 \\
\hline $\mathrm{i} 4 *$ PA2 & -0.146 & $\begin{array}{l}- \\
0.034\end{array}$ & 0.090 & 0.130 & 0.218 & $\begin{array}{l}- \\
0.013\end{array}$ & $\begin{array}{l}- \\
0.057\end{array}$ & 0.004 \\
\hline $\mathrm{i} 4 * \mathrm{PA} 3$ & -0.119 & 0.077 & 0.392 & 0.128 & 0.291 & 0.057 & 0.055 & 0.047 \\
\hline $\mathrm{i} 4 * \mathrm{PA} 4$ & -0.095 & 0.078 & 0.430 & 0.092 & 0.210 & 0.078 & 0.046 & 0.102 \\
\hline
\end{tabular}




\begin{tabular}{|c|c|c|c|c|c|c|c|c|}
\hline $\mathrm{i} 4 *$ PA5 & -0.185 & 0.054 & 0.427 & 0.124 & 0.112 & $\overline{0} .022$ & 0.080 & 0.051 \\
\hline $\mathrm{i5}$ & 0.623 & 0.222 & -0.044 & -0.054 & -0.094 & 0.167 & 0.226 & 0.166 \\
\hline $\mathrm{i} 5 * \mathrm{PA} 1$ & -0.024 & 0.005 & 0.207 & 0.190 & 0.217 & 0.085 & 0.020 & -0.045 \\
\hline i5 * PA2 & -0.051 & 0.004 & 0.214 & 0.186 & 0.257 & $\begin{array}{l}- \\
0.009\end{array}$ & $\begin{array}{l}- \\
0.007\end{array}$ & -0.054 \\
\hline i5* PA3 & -0.089 & 0.061 & 0.501 & 0.212 & 0.336 & 0.058 & 0.085 & 0.031 \\
\hline $\mathrm{i} 5 * \mathrm{PA} 4$ & -0.113 & 0.030 & 0.518 & 0.199 & 0.283 & 0.043 & 0.170 & 0.100 \\
\hline i5 * PA5 & -0.066 & 0.093 & 0.488 & 0.234 & 0.124 & 0.083 & 0.109 & 0.109 \\
\hline
\end{tabular}

Table 8 Heterotrait And Monotrait Ratio (HTMT)

\begin{tabular}{|l|l|l|l|l|l|l|l|l|}
\hline & INCOME & IB & $\begin{array}{l}\text { Moderating } \\
\text { Effect 1 }\end{array}$ & $\begin{array}{l}\text { Moderating } \\
\text { Effect 2 }\end{array}$ & $\begin{array}{l}\text { Moderating } \\
\text { Effect 3 }\end{array}$ & PA & PD & SE \\
\hline I & & & & & & & & \\
\hline IB & 0.406 & & & & & & & \\
\hline $\begin{array}{l}\text { Moderating } \\
\text { Effect 1 }\end{array}$ & 0.284 & 0.243 & & & & & & \\
\hline $\begin{array}{l}\text { Moderating } \\
\text { Effect 2 }\end{array}$ & 0.209 & 0.209 & 0.437 & & & & & \\
\hline $\begin{array}{l}\text { Moderating } \\
\text { Effect 3 }\end{array}$ & 0.247 & 0.080 & 0.584 & 0.412 & & & & \\
\hline PA & 0.542 & 0.620 & 0.292 & 0.204 & 0.088 & & & \\
\hline PD & 0.646 & 0.380 & 0.297 & 0.117 & 0.079 & 0.564 & & \\
\hline SE & 0.329 & 0.392 & 0.206 & 0.030 & 0.120 & 0.680 & 0.388 & \\
\hline
\end{tabular}

The above table 6 shows fornell-larcker criterion so as per according to the research of (FORNELL \& LARCKER, 1981) the square root of AVE or the diagonal values should be greater than the off diagonal values, whereas we can see on the above table 06 that all the diagonal values are greater than the off diagonal values. Moreover according to the research of (GEFEN \& STRAUB, 2005) in the cross loading table all the indicator should be greater in its own variable and lesser on the other variable, so we can see on the above table 07 all the indicators are greater in its own variable. According to the research of (JORG \& CRISTIAN, 2009) the acceptable value for HTMT is $<0.8$ and if the value is greater than 0.8 so it is not acceptable and not valid, whereas we can see on the above table 08 all the value are $<0.8$ which is according to the threshold value and acceptable. Hence all the above three table is according to the criteria so we can say that the table 6,7 and 8 shows discriminate validity.

Table 9. R-Square and Adjusted R-Square: 
In the above

r-square

is indicating

display, store

\begin{tabular}{|ll|l|l|}
\hline & & R Square & $\begin{array}{l}\text { R Square } \\
\text { Adjusted }\end{array}$ \\
\hline $\begin{array}{l}\text { IMPULSIVE } \\
\text { BEHAVIOR }\end{array}$ & BUYING & 0.652 & 0.615 \\
\hline
\end{tabular}

table 09, the

value 0.652

that product

environment

and promotional activity is explaining 65.2 variance in dependent variable impulsive buying behavior.

Table 9 Path Coefficients

\begin{tabular}{|l|l|l|l|l|l|}
\hline & $\begin{array}{l}\text { Original } \\
\text { Sample (O) }\end{array}$ & $\begin{array}{l}\text { Sample } \\
\text { Mean (M) }\end{array}$ & $\begin{array}{l}\text { Standard Deviation } \\
(\text { STDEV) }\end{array}$ & $\begin{array}{l}\text { T Statistics } \\
(|\mathrm{O} / \mathrm{STDEV}|)\end{array}$ & $\begin{array}{l}\text { P } \\
\text { Values }\end{array}$ \\
\hline I -> IB & 0.166 & 0.171 & 0.069 & 2.390 & 0.017 \\
\hline $\begin{array}{l}\text { Moderating } \\
\text { Effect 1 -> IB }\end{array}$ & 0.112 & 0.149 & 0.164 & 0.681 & 0.496 \\
\hline $\begin{array}{l}\text { Moderating } \\
\text { Effect 2 -> IB }\end{array}$ & 0.127 & 0.103 & 0.069 & 1.838 & 0.067 \\
\hline $\begin{array}{l}\text { Moderating } \\
\text { Effect 3 -> IB }\end{array}$ & -0.083 & -0.084 & 0.083 & 1.006 & 0.315 \\
\hline PA -> IB & 0.252 & 0.248 & 0.080 & 3.159 & 0.002 \\
\hline PD -> IB & 0.042 & 0.056 & 0.078 & 0.537 & 0.592 \\
\hline SE -> IB & 0.125 & 0.110 & 0.073 & 1.708 & 0.088 \\
\hline
\end{tabular}

According to the research of (FISHER, 1950) the null hypothesis is reject when the P value is $<0.05$ and $\mathrm{T}$ value is $>1.96$ and the null hypothesis is fail to reject criteria is when the $\mathrm{P}$ value is $>0.05$ and $\mathrm{T}$ value is $<1.96$. So we can see on the above table that shows the first relationship of income with impulsive buying behavior whose $\mathrm{p}$ value is less than 0.05 and $\mathrm{t}$ value is greater than 1.96 which shows that the null hypothesis is rejecting and there is a relationship between 
income and impulsive buying. The next three column show the moderation effect and the all three column $\mathrm{p}$ value is greater than 0.05 and $\mathrm{t}$ value is less than 1.96 which shows that we are fail to reject null hypothesis, so it mean than there is no effect of independent variable product display, store environment and promotional activity on impulsive buying with moderation income. Move towards the fifth column that shows the relationship between promotional activity and impulsive buying and there $\mathrm{p}$ value is less than 0.05 and $\mathrm{t}$ value is greater than 1.96 which shows that the null hypothesis is rejected and there is a positive relationship between promotional activity and impulsive buying. The sixth column shows the relationship between product display and impulsive buying and their $\mathrm{p}$ value is greater than 0.05 and $\mathrm{t}$ value is less than 1.96 which shows fail to reject null hypothesis and there is no relationship between these two variables. Moreover the last column shows the relationship between store environment and impulsive buying and their values shows fail to reject null hypothesis and there is no relationship because there $\mathrm{p}$ value is greater than 0.05 and $\mathrm{t}$ value is less than 1.96.

\section{CONCLUSION}

The present researcher concluded after the testing result that income itself has an effect on impulsive buying which indicated that people do unplanned purchases or impulsive purchasing by considering their money like if they do not have enough money or have tight budget they and something really attracts they may do impulsive purchasing and buy that product and they prefer or like to do unplanned purchasing when they go for shopping and have enough money to do unplanned purchase. Where as the result shows that income do not moderate between independent variable (store environment, product display, promotional activity) and dependent variable (impulsive buying behavior), which ultimately shows that all independent variable has their separate impact on impulsive purchasing ass it is concluded through research that store environment and product display do no effect impulsive buying behavior of customer which mean that comfortable and relaxed environment of superstores do not motivate them to do impulsive purchasing likewise store product display or attractive display do not influence them to do impulsive purchasing but on the other hand the third independent variable promotional activity shows a positive impact on impulsive purchasing which means people influence to do impulsive purchasing through different sales discount( buy on get one free, discount offers), advertisement, discount prices. Therefore it shows that the stores should consider different promotional activity to motivate them to do impulsive purchasing.

\section{RECOMMENDATIONS}


The present research main objective is to find out the relationship of moderation in between independent variable store environment, product display, promotional activity and impulsive buying behavior. Therefore according to the present researcher observation the incomes do not moderate between independent variable and dependent variable impulsive purchasing. Moreover it is observed that product display and store environment do not influence people to do impulsive purchasing whereas the promotional activity influence people and motivate them to do unplanned purchasing. Therefore the superstore should consider different promotional activities to motivate and attract more and more customer to do planned and unplanned purchases and provide them such prices and offers which they can afford and do more and more impulsive purchasing.

\section{LIMITATIONS}

The present research uses three independent variables and its impact on impulsive buying behavior with moderating role of income. The future researcher can use more factors like visual merchandising, cultural values and lifestyles; different demographic variable like age, gender, education could be use as moderator. One of the limitation is the sample size of data the future researcher could gather data from more respondents and sample size through which more accurate result could be obtain. The future researcher could generate data from more secondary sources and can use more authentic publish data for their research. The present researcher targeted Karachi city supermarkets, the future researcher could target different cities of Pakistan. 


\section{REFRENCES}

Abbasi, B. (2017). Relationship Between Consumer Characteristics And Impulse Buying Behavior. International Review Of Management And Marketing , 1 (7).

Alireza, K., \& Hasti, Y. (2011). Evaluating Effecting Factor On Consumer Impulsive Buying Behavior. Asian Journal Of Business Management Studies , 4 (2), 174-181.

Amitav, B., \& Suprakash, C. (2010). Statistics Without Tears: Population And Sample. 60-65.

Anita, S. C. (2012). The Impact Of Demographic, Situational And Socioeconomic Factor On Impulse Buying Behaviot. Journal Of East West Business , 208-230.

Anmol, R., Rana, S. M., \& Fahad, B. J. (2017). Factors Affecting Impulse Buying. Journal Of Marketing And Consumer Research, 39, 1-20.

Aysen, A. (2018). Determinant Factor Affecting Impulse Buying Behavior. International Journal Of Research In Business And Social Science , 1 (7), 1-10.

Creswell, W. J. (2002). Educational Research; Planning, Conducting And Evaluating Qualitative And Quantitative Research.

D., J. M., P., G., \& C. S. (2009). A Comprehensive Model Of Customer Trust. Journal Of Service Management , 20 (3), 290-316.

Fisher, R. (1950). Statistical Method For Research Workers.

Fornell, C., \& Larcker, D. (1981). Evaluating Structural Equational Model. Journal Of Marketing, 39-50.

Galis, T., \& Kabul, T. (2016). Stimulation Factor Of Impulsive Buying Behavior. 572-593.

Gaurav, S. (2011). Examining The Moderating Role Of Income In Relationship With Impulsive Buying Behavior And Visual Merchandising. 1-13.

Gefen, D., \& Straub, D. (2005). A Practical Guide To Factorial Validity. Science And Education , 91-109.

Hair, J., \& Black, C. (2014). Multivariate Data Analysis. 
Hassan, A., \& Hadiqa, R. (2018). Impact Of Store Environment On Impulse Buying. Kasbit Business Journal , 11, 57-76.

Hio, C. J., Ruoh, Y. N., \& Molly, E. (2014). Moderating Effect Of Situational Factor On Impulsive Buying Behavior. International Journal Of Retail And Distribution Management, 42 (4), 298-314.

Jamnani, A., \& Dhaddikar, P. (2015). Influence Of Visual Merchandising On Customer Buying Decision. Asia Pacific Journal Of Research , 1, 107-133.

Jiyeon, K. (2003). Impulse Buying Behavior In Relation To Visual Merchandising.

Jones, M., Reynolds, K., Weun, S., \& Beatty, S. (2003). The Product Specific Nature Of Impulsive Buying Tendency. Journal Of Business Research , 56, 11-505.

Jorg, H., \& Cristian, M. R. (2009). The Use Of Partial Least Square. International Marketing Journal , 277-320.

Mahshid, O. (2016). How Sales Promotion Effect Impulse Buying. 1-94.

Mudassir, H., Bushra, R., Fauzia, S., \& Muhammad, A. W. (2019). Personal And Instore Factor Affecting Impulsive Buying Behavior. Journal Of Usiness Perspective And Research , 1 (7), 92-107.

Parmar, V., \& Ahmed, R. R. (2013). Factor Influencing Impulsive Buying Behavior. European Journal Of Scientific Research , 100 (3), 1-13.

Peter, H., \& Vladimir, V. (2014). Promotion And Shopper Impulse Purchase The Example Of Clothes. Journal Of Consumer Marketing , 94-102.

Phillimore, J., \& Goodson, J. (2004). Qualitative Research On Tourism, Epistimolgies, Onthology And Methadologies.

Piyush, S., \& Geetha, M. (2013). Impact Of Store Environment On Impulsive Buying Behavior. European Journal Of Marketing , 47 (10), 1711-1732.

Rafia, A., \& Maira, Z. (2018). External Stimuli And Ipulsive Buying Behavior. Journal Of Management Sciences , 13 (1), 1-20.

Saunders, M., Lewis, P., \& Thronhill, A. (2007). Research Method For Business Students. 624. 
Sharma, P., \& Sivakumaran, B. (2010). Impulse Buying And Variety Seeking. Journal Of Business Research , 276-83.

Tavakol, ,. M., \& Dennick, ,. R. (2011). Making Sense Of Cronbach Alpha. International Journal Of Medical Education, 53-55.

Tendai, M., \& Crispen, C. (2009). In Store Shopping Environment And Impulsive Buying. Journalof Marketing Management , 4 (1), 102-108.

Umair, A., Peng, H., Muhammad, K. K., Muhammad, H., \& Shahid, R. (2016). Impact Of Store Atmosphere On Impulsive Buying With Moderating Role Of Demographic Variable. International Journal Of Science And Technology , 9 (7), 43-60.

Ume, S. (2010). Research Methadologies.

Vidha, P. (2016). Study On Impulsive Buying Behavior. Journal Of Business And Social Scince Research , 1 (2), 215-233.

Vohs, D. K. (2007). Self Regulatory Resources Availability Affect Impulse Buying Behavior. Journal Of Consumer Research , 537-547.

Zaeema, M. A., \& Haider, I. (2018). Relationship Of Demographic Factor And Impulsive Buying Behavior. Journal Of Marketing And Consumer Research , 46.

\section{APPENDIX}



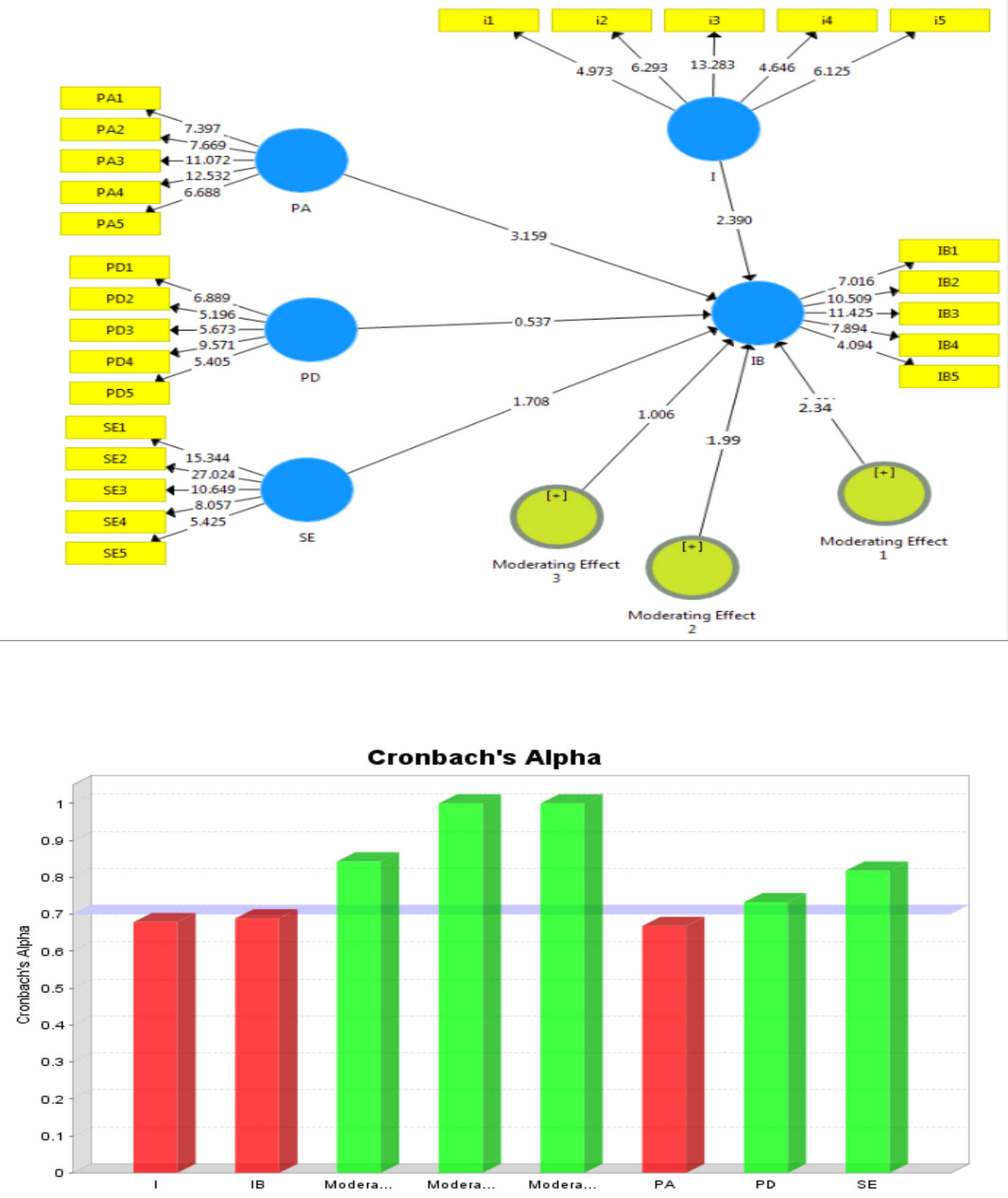


\section{Composite Reliability}

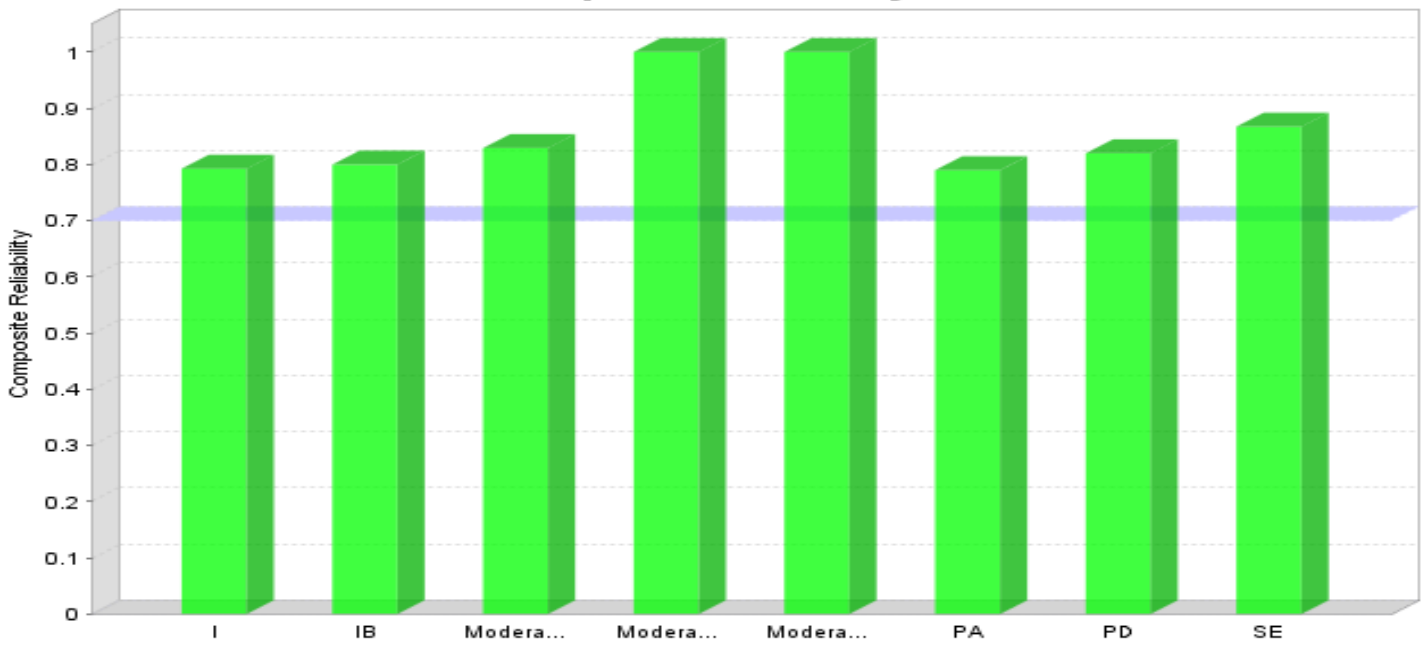

Heterotrait-Monotrait Ratio (HTMT)

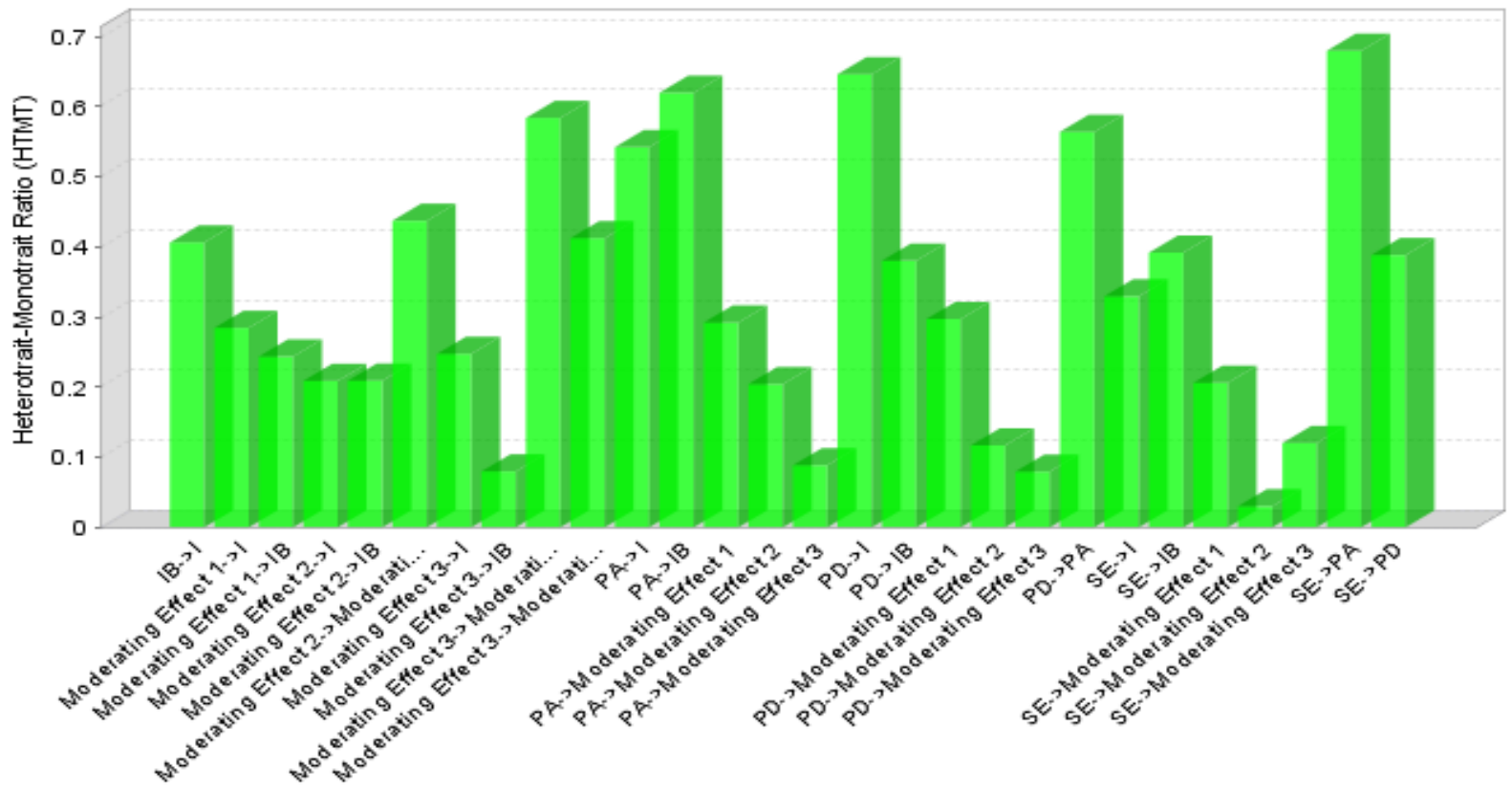

